IJCCS (Indonesian Journal of Computing and Cybernetics Systems)

Vol.14, No.4, October 2020, pp. 387 396

ISSN (print): 1978-1520, ISSN (online): 2460-7258

DOI: https://doi.org/10.22146/ijccs.58298

\title{
The Strategy of Enhancing Employee Reward Using TOPSIS Method as a Decision Support System
}

\author{
Untung Rahardja ${ }^{1}$, Ninda Lutfiani ${ }^{*}{ }^{2}$, Sudaryono $^{3}$, Rochmawati ${ }^{4}$ \\ ${ }_{1,2,3,4}$ Magister program Informatics Department, Faculty of Science and Technology, Universitas \\ Raharja, Indonesia \\ E-mail: ${ }^{1}$ untung@ raharja.info, *²ninda@ raharja.info, ${ }^{3}$ sudaryono@ raharja.info, \\ ${ }^{4}$ rochmawati@ raharja.info
}

\begin{abstract}
Abstrak
Pemberian reward atas kinerja yang baik dan pencapaian tugas sangat perlu dilakukan sebagai bentuk pengakuan dan penghargaan oleh organisasi/institusi kepada pegawai, sekaligus menjadi bagian proses pencapaian tujuan organisasi. Penelitian ini bertujuan mengembangkan sistem pendukung keputusan menggunakan metode Technique for Order of Preference by Similarity (TOPSIS) dengan bahasa pemrograman PHP untuk memilih pegawai penerima reward pada universitas. Data yang digunakan berasal dari 2 kelompok yaitu tenaga edukatif (dosen) dan tenaga non edukatif (pegawai). Kriteria penentu yang diterapkan pada kelompok tenaga edukatif sebanyak 10 hal, yaitu: masa kerja, nilai DP3, nilai pada persentase kehadiran kerja, nilai pada persentase kehadiran mengajar, nilai atas jabatan fungsional dosen, nilai atas pelaksanaan penelitian, nilai atas pelaksanaan pengabdian masyarakat, nilai atas hasil kuesioner oleh mahasiswa, nilai atas status kepegawaian, dan nilai atas sanksi. Kriteria penentu yang digunakan pada kelompok non edukatif sebanyak 5 hal, yaitu: masa kerja, nilai DP3, nilai persentase kehadiran kerja, nilai atas status kepegawaian, dan nilai atas sanksi. Hasil penelitian ini berupa sebuah program sistem informasi sebagai alat bantu pengambilan keputusan untuk proses pemilihan pegawai penerima reward.
\end{abstract}

Kata kunci-Metode TOPSIS, Pegawai, Reward, Sistem Penunjang Keputusan

\begin{abstract}
Giving rewards for good performance and achievement of tasks needs to be done as a form of recognition and appreciation by the organization/institution to employees, as well as being part of the process of achieving organizational goals. This study aims to develop a Decision Support System that uses the Technique for Order of Preference by Similarity (TOPSIS) method with the PHP programming language to select reward recipients at University. The data used came from 2 groups, namely educational staff (lecturers) and non-educative staff (employees). Determination criteria applied to the educative group are 10 things, namely: tenure, DP3 value, the value on the percentage of work attendance, value on the percentage of teaching attendance, value on lecturer functional position, value on research implementation, the value on implementation of community service, value on the results of the questionnaire by students, the value of employment status, and the value of sanctions. There are 5 determinant criteria used in the non-educative group, namely: tenure, DP3 value, percentage of work attendance, the value of employment status, and value of sanctions. The results of this study are in the form of an information system program as a decision-making tool for the process of selecting reward recipient employees.
\end{abstract}

Keywords-TOPSIS Method, Employee, Reward, Decision Support System

Received July $30^{\text {th }}, 2020$; Revised October $30^{\text {th }}$, 2020; Accepted October $31^{\text {th }}, 2020$ 


\section{INTRODUCTION}

Higher Education As the organizer has a strategic role in increasing the nation's competitiveness in facing globalization in all fields. According to the law Number 12 of 2012 concerning Higher Education, that the functions and roles of Higher Education areas A forum for student and community learning, Education Containers for prospective national leaders, Science and Technology Development Center, Center for the study of virtue and moral strength to seek and find the truth, and center for the development of national civilization. Universities make changes, but often do not monitor improvements to ensure their level of success over time [1]. Improvements can work in the short term and fail over time because many campuses are returning to the old ways of doing things. There is pressure, both internally and externally, to withstand rising costs. Higher education is a place for students to work with teaching lecturers and staff who deserve compensation for the knowledge, skills, and experience they bring to the institution [2]. Human resource management recognized as crucial for the realization of objectives, but leading is challenging and complicated. In addition to being able, competent, and skilled human labour is no less critical in their ability to work effectively and efficiently. Expertise and skills are less meaningful if not accompanied by good work morals that will support realizing goals. This development requires that human resource management is needed to ensure the quality of the services it provides to its clients, especially for students [3].

Achieving the goals of an organization is determined not only by the number of funds owned, the technology used or facilities, and infrastructure but also by human resources, which is one of the most crucial factors to consider [4] [5]. This factor drives all the elements possessed by the organization in the process of achieving goals. Employee factors play an essential role in achieving organizational goals, the quality of employees both individually and as teamwork [6]. Instructional staff, in the future, referred to as Lecturers, are assigned as functional staff responsible for implementing the Higher Education Tri Dharma, namely education and teaching, research, and community service following their field of knowledge. Non-educative employees in the future, referred to as staff, are employees who placed as supporting teams for the implementation of academic activities and outside educational activities.

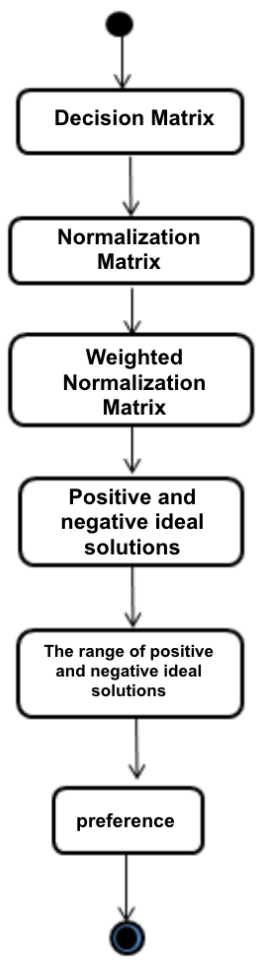

Figure 1. TOPSIS Computing Activity Diagram 
The research conducted is to make a decision support system in the form of an information system that can provide consideration in making decisions regarding the selection of reward recipients in Figure 1. The method using TOPSIS (Technique for Order Performance by Similarity to Ideal Solution). The programming languages used are PHP and MySQL databases. The ability to make fast and careful decisions is the key to success in global competition, which requires analysis and calculation, depending on the number of criteria that affect the problem that requires a decision. Therefore, a computer-based system is needed that used to determine employee reward recipients.

This study aims to achieve the objectivity of the results of the employee selection system decision with the criteria used in determining the recipient of employee rewards consisting of two classifications, namely lecturers based on tenure criteria, the value of the Job Implementation Assessment List (DP3), the amount of the percentage of attendance, the value of the percentage of teaching attendance, position functional, research value, service value, questionnaire value, employment status, sanctions and employees based on criteria: length of service, the amount of Work Implementation Assessment List (DP3), percentage of attendance value, employment status, sanctions to get a reward.

The best alternative in the decision-making system for selecting employee recipients of awards using the TOPSIS (Technique for Order Performance by Similarity to Ideal Solution) method. The decision support system used as a tool to select reward recipients so that the Chancellor can make decisions based on the system recommendations made.

\section{METHODS}

There are 2 (two) types of awards, namely those consisting of financial (outward) and those composed of non-financial (intrinsic), and can use positively to affect employee performance improvement [7]. Monetary awards related to performance awards include bonuses, promotions, positions, commissions, tips, giving and gifts, etc. Non-financial awards in the form of money approved in the form of community awards, praise, etc. Recognition and appreciation are other related components that are part of the giving strategy. Recognition is carried out by a colleague against someone for the behaviour requested or received obtained, actions taken positively. On the other hand, the award is more in the form of giving to employees because of their efforts. This award can improve their performance and provide them with a signal to do good or bad [8].

Extrinsic rewards decrease, while higher prices are pushed/strengthened because of intrinsic rewards [9]. At the same time, inherent rewards fulfil fundamental employee factors or motivation [10]. For example: giving a challenging task, asking for it in the process of making a decision, giving an improved choice, etc. It does not mean that what has to pay higher will increase workers' work better than what has to consider.

The award recognized a critical instrument relating to employee awards that are wellreceived awards approved by the company where the employee works explicitly [11]. Significant intrinsic rewards on employee performance and interrelated relationships, the prior coefficient of approval is that there is a strong relationship/support between rewards and employee performance [12]. One form of appreciation that can motivate employees is to give

The Strategy of Enhancing Employee Reward Using TOPSIS Method as a ... (Ninda Lutfiani) 
awards in the way of money as a form of recognition for excellent performance and as a step to maintain employee loyalty.

A literature review conducted to study the development of the particular TOPSIS method for award decision support systems for staff and faculty in tertiary institutions. Several related studies examined, one of which showed the value of positive and negative ideal solutions of each sub-criterion obtained by finding the maximum value in each sub-criterion because all sub-criteria were beneficial [13]. The same thing finds in the TOPSIS method's use, which is to determine employees in the company who can fulfil a sense of justice with the same criteria as the selection of award recipient employees [14].

TOPSIS method used in solving problems that can endanger companies with measures to meet market needs and reduce the build-up of goods [15] [16], also found in other studies that use this method to find the best data [17] [18]. Other studies use the TOPSIS method to resolve the issue of government assistance accounts for financial assistance. Hence, the problem-solving process needs to done using a decision-making system [19] [20]. It can found between the TOPSIS and SAW methods. The results obtained by the TOPSIS method are more appropriate to use in customer rewards [21], not only that other studies discussing the technique of supporting decision making systems that made to assist in selecting thesis titles provided by field rankings science [22].

Calculating the opinion of award criteria to improve company performance, improve valuation, is used to measure financial performance [23] [24] employees who get significant results do not have definite plans on participants, and some of them are neutral [25] [26]. The fuzzy intuitionistic TOPSIS method is advantageous for improving human resources and improving the overall quality of the company [27].

The results of the literature studies that collected synthesized that the Technique for Order of Preference by Similarity (TOPSIS) method can be used comprehensively for decision support systems. Still, there has been no research into strategies to increase employee appreciation, especially at the University. In line with the background and reviewing the previous study, it further develops.

Make a decision matrix following the problem to be solved with the following conditions:

$$
D=\left[\begin{array}{ccc}
x 11 & x 12 \ldots & x 1 n \\
x 21 & x 22 \ldots & x 2 n \\
\ldots & \ldots & \ldots \\
x m 1 & x m 2 \ldots & x m n
\end{array}\right]
$$

Matrix normalization with the equation:

$$
r_{i j}=\frac{x_{i j}}{\sqrt{\sum_{i=1}^{m} x_{i j}^{2}}}
$$

Where rij is the normalized matrix of the basic matrix of the problem, with $i=1,2,3, \ldots . \mathrm{m}$, and $\mathrm{j}$ $=1,2,3 \ldots \mathrm{n}$. Whereas $\mathrm{xij}$ is the basic matrix that will be normalized. For each $\mathrm{i}$ denotes the row of the matrix, each $\mathrm{j}$ denotes the column of each matrix.

IJCCS Vol. 14, No. 4, October 2020 : 387 - 396 
Normalization of the Rij matrix uses a weight rating so that the normalized weight rating matrix obtained; the equation used is as follows:

$$
\mathrm{y}_{\mathrm{ij}}=\mathrm{w}_{\mathrm{i}} \cdot \mathrm{r}_{\mathrm{ij}}
$$

$\mathrm{y}_{\mathrm{ij}}$ is the weighted rating matrix, wi is the weight of the rating to $\mathrm{i}$, and rij is the normalized matrix in step two. For $\mathrm{i}=1,2, \ldots, \mathrm{m}$, and $\mathrm{j}=1,2, \ldots, \mathrm{n}$. In this case, the rating weight must be determined based on the number of decision variables resolved. The positive ideal solution (A + ) and the negative ideal solution (A-) based on the weighted rating matrix in step 3. The following equation used to find the value of a positive ideal solution and the value of a negative ideal solution.

$$
\begin{aligned}
A^{+} & =\left(y_{1}^{+}, y_{2}^{+}, \ldots, y_{n}^{+}\right) \\
A^{-} & =\left(y_{1}^{-}, y_{2}^{-}, \ldots, y_{n}^{-}\right)
\end{aligned}
$$

Determine the distance between the weighted value of each alternative to the positive ideal solution and the negative ideal solution. To determine the distance between the weighted values from each alternative to the positive ideal solution, use the following equation:

$$
D_{i}^{+}=\sqrt{\sum_{i=1}^{n}\left(y_{i}^{+}-y_{i j}\right)^{2}}
$$

For calculating the distance between the weighted values of each alternative to the negative ideal solution, the following equation:

$$
D_{i}^{-}=\sqrt{\sum_{i=1}^{n}\left(y_{i j}-y_{i}^{-}\right)^{2}}
$$

The final step is to calculate the preference value for each option by comparison:

$$
V_{i}=\frac{D_{i}^{-}}{D_{i}^{-}+D_{i}^{+}}
$$

\section{RESULTS AND DISCUSSION}

The TOPSIS method widely used to complete practical decision making. It causes the concept is simple and easy to understand, efficient computation, and can measure the relative performance of decision alternatives. The second method developed in this study uses the Waterfall Development Life Cycle (SDLC) Software, according to the following image: 


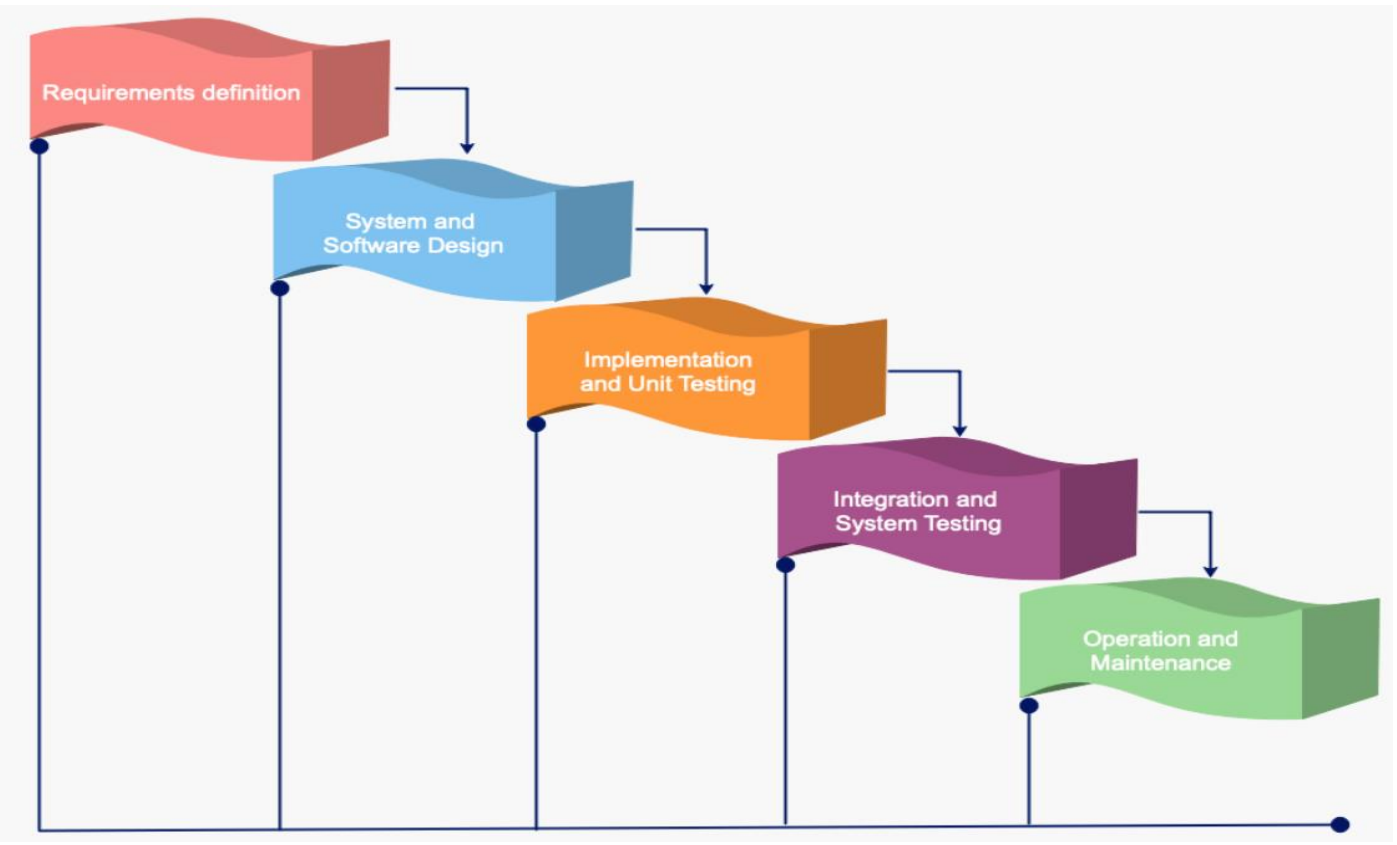

Figure 2. SDLC Waterfall

Figure 2. explains the stages of the Waterfall Development Life Cycle (SDLC) process, which consists of requirements definition, system and software design, implementation and unit testing, integration and system testing, operation, and maintenance. Also, looking at the problem of decision making is the process of finding the best option for all feasible alternatives.

Decision-making criteria are part of a relatively complex problem. It involves several decision-makers with an infinite number of rules that must consider. Each approach has a specific weight value that intends to get the optimal solution for a problem. One method to deal with this problem is a Technique for Order Performance by Similarity to Ideal Solution (TOPSIS).

A decision support system for selecting employee recipients of reward applied in an integrated information system in the staffing system. The following describes the results of using the TOPSIS method for determining employee rewards.

\begin{tabular}{llllllllll} 
A2 & 1 & 2 & 2 & 2 & 1 & 1 & 3 & 3 & 4 \\
A3 & 3 & 3 & 4 & 3 & 1 & 3 & 2 & 3 & 3 \\
A4 & 3 & 2 & 2 & 2 & 2 & 2 & 2 & 2 & 4 \\
A1 & 1 & 3 & 4 & 3 & 2 & 2 & 3 & 3 & 2 \\
\hline
\end{tabular}

Figure 3. TOPSIS Computing Lecturer (Alternative Weighting)

In figure 3, the TOPSIS computation form will appear in the assessment period, after selecting the assessment period, the TOPSIS computation data will perform according to the weight matrix. 


$\begin{array}{lllllll}\text { A2 } & 0.22360679774998 & 0.30860669992418 & 0.26726124191242 & 0.30860669992418 & 0.31622776601684 & 0.17149858514251 \\ \text { A3 } & 0.67082039324994 & 0.46291004988628 & 0.53452248382485 & 0.46291004988628 & 0.31622776601684 & 0.51449575542753 \\ \text { A4 } & 0.67082039324994 & 0.30860669992418 & 0.26726124191242 & 0.30860669992418 & 0.63245553203368 & 0.34299717028502 \\ \text { A1 } & 0.22360679774998 & 0.46291004988628 & 0.53452248382485 & 0.46291004988628 & 0.63245553203368 & 0.34299717028502\end{array}$

Figure 4. TOPSIS Computing Lecturer (Normalization Matrix)

The computation of TOPSIS Lecturers (Normalization Matrix) in figure 4 displayed calculations using the TOPSIS method, which shows the normalization matrix of lecturer data and lecturer assessments in the specified assessment period.

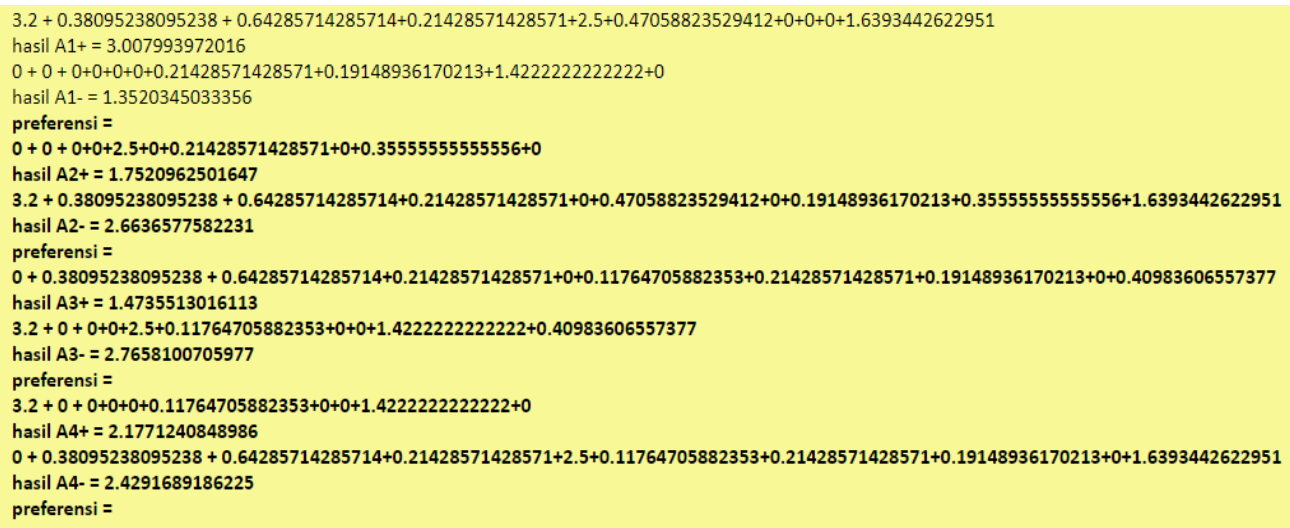

Figure 5. Calculation of a definite ideal positive and a negative solution

TOPSIS Computation of Lecturers (Preference and Ranking) in Figure 6 calculations using the TOPSIS method, which is the calculation of preference and ranking of lecturer and lecturer data in the specified period. In the end, the results of the assessment using the TOPSIS method will reward the leader for choosing the recipient of the prize.

\section{CONCLUSION}

In calculating the determination of reward recipients in the University the criteria used in determining the achievement of objectivity of the results of the employee selection system with the rules used in determining the recipient of a reward, employees consist of two classifications, namely lecturers based on work tenure criteria, the value of the Job Implementation Assessment List, the amount of the percentage of attendance, the value of the rate of teaching attendance, functional position, the cost of research, the value of service, the value of the questionnaire, employment status, sanctions and employees based on the criteria of tenure, the value of the Job Implementation Assessment List (DP3), the percentage of attendance value, employment status, sanctions to get a reward.

By using a decision support system as a tool in determining employee, reward recipients can provide the best alternative by utilizing the TOPSIS (Technique for Order Performance by Similarity to Ideal Solution) method, the objectivity decision result of the employee selection system will be achieved compared to the manual operation and can present the required reports. 
The decision support system used as a tool to select reward recipients so that the Chancellor can make decisions based on the system recommendations made.

The TOPSIS (Technique for Order Performance by Similarity to Ideal Solution) method can be applied not only to determine the recipient of reward employees but also to other problem-solving. Criteria and Weights used in determining employee reward recipients can develop to improve system development. The use of the Decision Support System method can use different ways to be used as a comparison of values and rankings produced for system development.

\section{ACKNOWLEDGEMENTS}

We would like to thank the Ministry of Research and Technology/National Agency for Research and Innovation (RISTEK-BRIN) for funding this research. Special thanks to Universitas Raharja, especially to Alphabet Incubator.

\section{REFERENCES}

[1] U.-U. R. I. Nomor, "tahun 2012 tentang Pendidikan Tinggi." 12AD.

[2] W. K. Balzer, Lean higher education: Increasing the value and performance of university processes. CRC Press, 2020.

[3] R. M. Bañez and R. M. Latido, "Examining the Management of Human Resources in Campus-Based Student Publication," no. 7, pp. 125-133, 2018.

[4] M. Abdel-Basset, M. Saleh, A. Gamal, and F. Smarandache, "An approach of TOPSIS technique for developing supplier selection with group decision making under type-2 neutrosophic number," Appl. Soft Comput. J., vol. 77, pp. 438-452, 2019, doi: 10.1016/j.asoc.2019.01.035.

[5] M. Okumura, "How to ignite a rocket heading for the system update? workshop for training human resources toward updating the campus information system," Proc. ACM SIGUCCS User Serv. Conf., pp. 15-20, 2018, doi: 10.1145/3235715.3235717.

[6] J. Seyedmohammadi, F. Sarmadian, A. A. Jafarzadeh, M. A. Ghorbani, and F. Shahbazi, "Application of SAW, TOPSIS and fuzzy TOPSIS models in cultivation priority planning for maize, rapeseed and soybean crops," Geoderma, vol. 310, no. January, pp. 178-190, 2018, doi: 10.1016/j.geoderma.2017.09.012.

[7] G. Tang, Y. Chen, Y. Jiang, P. Paillé, and J. Jia, "Green human resource management practices: scale development and validity," Asia Pacific J. Hum. Resour., vol. 56, no. 1, pp. 31-55, 2018, doi: 10.1111/1744-7941.12147.

[8] Sudaryono, U. Rahardja, and N. Lutfiani, "The Strategy of Improving Project Management Using Indicator Measurement Factor Analysis (IMF) Method," in Journal of Physics: Conference Series, 2020, vol. 1477, no. 3, doi: 10.1088/17426596/1477/3/032023.

[9] R. Intan, "Sistem Penghargaan Sebagai Solusi Peningkatan Kinerja Dosen," J. Adm. DAN Kebijak. PUBLIK, vol. 7, no. 1, pp. 47-57, 2017.

[10] G. Wibisono, A. Amrulloh, and E. I. H. Ujianto, "Penerapan Metode TOPSIS Dalam Penentuan Dosen Terbaik," Ilk. J. Ilm., vol. 11, no. 2, pp. 102-109, 2019. 
[11] U. Rahardja, N. Lutfiani, and H. L. Juniar, "Scientific Publication Management Transformation In Disruption Era," Aptisi Trans. Manag., vol. 3, no. 2, pp. 109-118, 2019.

[12] H. W. Lee, J. Pak, S. Kim, and L. Z. Li, "Effects of Human Resource Management Systems on Employee Proactivity and Group Innovation," J. Manage., vol. 45, no. 2, pp. 819-846, 2019, doi: 10.1177/0149206316680029.

[13] I. Saputra and R. Wardoyo, "Sistem Pendukung Keputusan Kelompok Penentu karyawan terbaik menggunakan metode Topsis dan Borda," IJCCS (Indonesian J. Comput. Cybern. Syst., vol. 11, no. 2, pp. 165-176, 2017.

[14] P. Arbelia, "Penerapan Metode AHP Dan TOPSIS Sebagai Sistem Pendukung Keputusan Dalam Menentukan Kenaikan Jabatan Bagi Karyawan," J. Ilm. Go Infotech, vol. 20, no. 1, pp. 9-17, 2014.

[15] B. A. Benning, I. F. Astuti, and D. M. Khairina, "Sistem Pendukung Keputusan Pembelian Perangkat Komputer Dengan Metode Topsis," J. Inform. Mulawarman, vol. 11, no. 2, pp. 1-7, 2015.

[16] F. Agustin, S. Syafnidawati, N. P. Lestari Santoso, and O. G. Amrikhasanah, "Blockchain-based Decentralized Distribution Management in E-Journals," Aptisi Trans. Manag., vol. 4, no. 2, pp. 107-113, 2020.

[17] A. N. Fitriana, H. Harliana, and H. Handaru, "Sistem pendukung keputusan untuk menentukan prestasi akademik siswa dengan metode TOPSIS," Creat. Inf. Technol. J., vol. 2, no. 2, pp. 153-164, 2015.

[18] A. Rasyid and S. Maharani, "Implementasi Technique For Order Preferences By Similary To Ideal Solution (TOPSIS) Pada Seleksi Asisten Laboratorium (Studi kasus: Laboratorium RPL FMIPA Universitas Mulawarman)," 2017.

[19] D. Fatmawati and S. Sultoni, "Sistem Pengambilan Keputusan kelayakan bagi calon penerima dana bantuan masyarakat miskin menggunakan metode topsis berbasis web," JIMP-Jurnal Inform. Merdeka Pasuruan, vol. 1, no. 1, 2016.

[20] Sudaryono, N. Lutfiani, Suseno, and Q. Aini, "Empirical study of research performance leading to education 4.0 using the ilearning method," Int. J. Adv. Trends Comput. Sci. Eng., vol. 8, no. 51.5 Special Issue, pp. 264-268, 2019, doi: 10.30534/ijatcse/2019/4681.52019.

[21] A. P. Windarto, "Implementasi metode topsis dan saw dalam memberikan reward pelanggan,” Kumpul. J. Ilmu Komput, vol. 4, no. 1, pp. 88-101, 2017.

[22] R. R. Panggali, F. Marisa, and D. Purnomo, "SISTEM PENDUKUNG KEPUTUSAN UNTUK MENENTUKAN JUDUL SKRIPSI JURUSAN TEKNIK INFORMATIKA MENGGUNAKAN METODE TOPSIS,” JIMP-Jurnal Inform. Merdeka Pasuruan, vol. 2, no. 1, 2017.

[23] I. Korir and D. Kipkebut, "The effect of reward management on employees commitment in the universities in Nakuru County-Kenya," J. Hum. Resour. Manag., vol. 4, no. 4, pp. 37-48, 2016.

[24] A. Gündoğdu, "Measurement of financial performance using TOPSIS method for foreign banks of established in Turkey between 2003-2013 years," Int. J. Bus. Soc. Sci., vol. 6, no. 1, pp. 139-151, 2015.

[25] R. Ranjan and U. Mishra, "Impact of rewards on employee performance: a case of Indian oil corporation, Patna Region," IOSR J Bus Manag (IOSR-JBM), e-ISSN, pp. 22-30, 2017. 
[26] U. Rahardja, Q. Aini, Y. I. Graha, and N. Lutfiani, "Validity of Test Instruments," in Journal of Physics: Conference Series, 2019, vol. 1364, no. 1, p. 12050.

[27] W. Yinghui and L. Wenlu, "The application of intuitionistic fuzzy set TOPSIS method in employee performance appraisal," Int. J. u-and e-Service, Sci. Technol., vol. 8, no. 3, pp. 329-344, 2015. 